\title{
Observations of crayfish plague infections in commercially important narrow-clawed crayfish populations in Turkey
}

\author{
Harri Kokko ${ }^{1}$, Muzaffer M. Harlioglu², Hamdi Aydin ${ }^{3}$, Jenny Makkonen ${ }^{1}$, Gökhan Gökmen ${ }^{4}$, \\ Önder Aksu ${ }^{5}$ and Japo Jussila, \\ ${ }^{1}$ Department of Environmental and Biological Sciences, University of Eastern Finland, Kuopio Campus, P.O. Box 1627, \\ 70211 Kuopio, Suomi-Finland \\ ${ }^{2}$ Fisheries Faculty, Firat University, 23119 Elazig, Turkey \\ ${ }^{3}$ Gazanfer Bilge Vocational School, Kocaeli University, Karamürsel, Kocaeli, Turkey \\ ${ }^{4}$ Biological and Medical Laboratory Research, HAN University of Applied Sciences, Kapittelweg 33 (B0.02), \\ 6525 EN Nijmegen, Netherlands \\ ${ }^{5}$ Fisheries Faculty, Munzur University, Tunceli, Turkey
}

\begin{abstract}
We studied the presence of possible Aphanomyces astaci infections in eight Turkish narrowclawed crayfish (Astacus leptodactylus) populations by analyzing the prevalence and genotypes of the disease agent $A$. astaci. The qPCR analyses revealed $A$. astaci infection in seven of the studied eight populations, with the agent level $\mathrm{A} 2$ or higher. The agent levels among the infected populations varied from $\mathrm{A} 0$ to $\mathrm{A} 5$, i.e., from negative to high level of infection, based on qPCR ranking. Based on the sequencing of the chitinase gene and the mitochondrial ribosomal $\mathrm{rnnS}$ and rnnL subunits, we detected both $\mathrm{A}(\mathrm{As})$ and $\mathrm{B}$ (PsI) haplogroups of $A$. astaci in our samples, with each of the studied populations being carriers of only one haplotype. The results confirm previous detections of $A$. astaci in Turkish narrow-clawed crayfish populations and reveal, that both $\mathrm{A}$ and B haplogroup A. astaci carriers exist widely in A. leptodactylus populations of Turkey.
\end{abstract}

Keywords: Astacus leptodactylus / Aphanomyces astaci / Turkey

Résumé - Observations sur l'infection de la peste de l'écrevisse dans des populations d'écrevisses à pattes grêles d'importance commerciale en Turquie. Nous avons étudié la présence possible d'Aphanomyces astaci dans huit populations turques d'écrevisses à pattes grêles (Astacus leptodactylus) en analysant la prévalence et les génotypes de l'agent pathogène $A$. astaci. Les analyses qPCR ont révélé une infection à $A$. astaci dans sept des huit populations étudiées, avec le niveau d'agent A2 ou plus. Les taux d'agents chez les populations infectées variaient de $\mathrm{A} 0$ à $\mathrm{A} 5$, c'est-à-dire du niveau négatif au niveau élevé d'infection, selon le classement qPCR. En se basant sur le séquençage du gène de la chitinase et des sousunités rnnS et rnnL du ribosome mitochondrial, nous avons détecté les haplogroupes A (As) et B (PsI) d' $A$. astaci dans nos échantillons, chacune des populations étudiées n'étant porteuse que d'un seul haplotype. Les résultats confirment les détections précédentes d' $A$. astaci dans les populations d'écrevisses à pattes grêles et révèlent que les porteurs des deux haplogroupes d'A. astaci existent largement dans les populations d' $A$. leptodactylus de Turquie.

Mots-clés : Astacus leptodactylus / Aphanomyces astaci / Turquie

The narrow-clawed crayfish, Astacus leptodactylus, is the only native freshwater crayfish species in Turkey. In addition to its natural distribution, it has also been widely introduced into lakes, reservoirs and rivers in many parts of the country because of its economic importance and restoration of the

*Corresponding author: japo.jussila@uef.fi crayfish stocks previously devastated by Aphanomyces astaci infections (Harlioglu, 2008). The narrow-clawed crayfish has been reported either to have some resistance against $A$. astaci (Unestam, 1969) or being very susceptible to $A$. astaci infection (Schikora, 1906; Alderman et al., 1987).

The Turkish narrow clawed crayfish populations got infected with A. astaci in early 1980's (Rahe and Soylu, 1989; Timur, 1990; Alderman, 1996; Kokko et al., 2012; Svoboda et al., 2012) 
Table 1. Aphanomyces astaci in Turkish narrow-clawed crayfish (A. leptodactylus) populations from eight lakes. Agent level A0 and A1 (>5 PFU's) indicates negative samples, A2 (5-50 PFU's) very low level infection, A3 (50-1000 PFU's) low level infection, agent level A4 (10 ${ }^{3}-$ $10^{4}$ PFU's) moderate infection and agent level A5 $\left(10^{5}-10^{6} \mathrm{PFU}\right.$ 's $)$ a high level infection. Abbreviations As= As genotype $A$. astaci, commensurate to mitochondrial haplogroup A; PsI=PsI-genotype $A$. astaci, commensurate to mitochondrial haplogroup B.

\begin{tabular}{|c|c|c|c|c|c|c|c|c|c|c|c|}
\hline \multirow[t]{2}{*}{ Lake (City) } & \multirow{2}{*}{$\begin{array}{l}\text { Gross } \\
\text { symptoms }(\%)^{2}\end{array}$} & \multirow{2}{*}{$\begin{array}{l}\text { Crayfish } \\
(n)\end{array}$} & \multicolumn{6}{|c|}{ A. astaci agent level in qPCR $(n)$} & \multirow{2}{*}{$\begin{array}{l}\text { Chitinase } \\
(n)\end{array}$} & \multicolumn{2}{|c|}{ Mt haplogroup } \\
\hline & & & A0 & A1 & $\mathrm{A} 2$ & A3 & A4 & A5 & & $\operatorname{rnnS}(n)$ & $\operatorname{rnnS}(n)$ \\
\hline Lake Iznik (Bursa) & $10-15$ & $20^{3}$ & & 1 & 5 & 10 & 2 & 2 & As (3) & & \\
\hline Lake Porsuk Dam (Kütahya) & $1.5-10$ & 5 & & & 2 & 2 & 1 & & & A (1) & \\
\hline Lake Çıldır (Ardahan) & $0.8-5$ & 5 & 1 & 1 & 1 & 1 & 1 & & & A (1) & A (1) \\
\hline Lake Sarımsaklı Dam (Kayseri) & $1-5$ & 5 & & 1 & 2 & & 2 & & & A (1) & \\
\hline Lake Yenikarpuzlu Dam (Edirne) & $3.5-12.5$ & 4 & 1 & 1 & & & 1 & 1 & PsI (2) & $\mathrm{B}(1)$ & B (1) \\
\hline Lake Hirfanlı Dam (Kırsehir) & $4.5-15$ & $20^{3}$ & 1 & & 9 & 9 & 1 & & PsI (2) & & \\
\hline Lake Hirfanlı Dam (Kırsehir) & $4.5-15$ & 5 & & & 2 & 2 & 1 & & & $\mathrm{~B}(2)$ & $\mathrm{B}(1)$ \\
\hline Lake Egirdir (Isparta) $^{1}$ & $0.8-12$ & 5 & & 1 & 4 & & & & & & \\
\hline Lake Keban Dam (Elazıg) & 0 & 6 & 4 & 2 & & & & & & & \\
\hline
\end{tabular}

${ }^{1}$ A. astaci infection of PsI genotype reported by Svoboda et al. (2014).

${ }^{2}$ Harlıoglu (unpublished).

${ }^{3}$ Kokko et al. (2012) published the qPCR results from sampling year 2011.

with a devastating effect on the crayfisheries and crayfish export (Harlıglu, 2004; Harlıoglu and Harlıglu, 2006; Aydın et al., 2012; Kokko et al., 2012). Later, it was discovered, that some of the collapsed narrow-clawed crayfish populations recovered (Harlıglu, 2008; Güner and Harlıglu, 2010). However, recent reports indicated, that some populations were chronically infected with $A$. astaci (Kokko et al., 2012; Svoboda et al., 2012, 2014). Furthermore, it has been reported that both freshwater crayfish and freshwater crabs are $A$. astaci carriers in Turkish waters (Svoboda et al., 2014).

Initially, some of the Turkish A. leptodactylus populations collapsed and never recovered (e.g., Harloglu, 2008), an indication of limited resistance against $A$. astaci infection. On the other hand, some Turkish A. leptodactylus populations chronically infected with $A$. astaci are productive, such as those in Lake İznik (Bursa) and Lake Hirfanlı Dam (Kırsehir) (Kokko et al., 2012). The observed latent infections may indicate past and contemporary partial resistance in the host, as has been argued by Unestam (1969) or even virulence evolution of $A$. astaci (Jussila et al., 2015).

The aim of this study was to investigate the distribution of A. astaci in wild narrow-clawed crayfish populations in Turkey. We selected narrow-clawed crayfish from eight populations, which were either showing potential gross symptoms of $A$. astaci infection, i.e., melanisation, necrosis or erosion of carapace, or were reported to be $A$. astaci infected (Tab. 1). Crayfish $(n=35)$ were bought from commercial crayfishermen from each location. They were caught during summer 2011 and 2012 from Lake Hirfanlı Dam, Kursehir $\left(39^{\circ} 11^{\prime} \mathrm{N} 33^{\circ} 33^{\prime} \mathrm{E}\right)$, Lake Iznik, Bursa $\left(40^{\circ} 43^{\prime} \mathrm{N} 29^{\circ} 52^{\prime} \mathrm{E}\right)$, Lake Egirdir, Isparta $\left(38^{\circ} 00^{\prime} \mathrm{N} 30^{\circ} 53^{\prime} \mathrm{E}\right)$, Lake Çıldır, Ardahan $\left(41^{\circ} 03^{\prime} \mathrm{N} 43^{\circ} 14^{\prime} \mathrm{E}\right)$, Lake Porsuk Dam, Kütahya $\left(39^{\circ} 38^{\prime} \mathrm{N}\right.$ $\left.30^{\circ} 11^{\prime} \mathrm{E}\right)$, Lake Sarımsaklı Dam, Kayseri ( $\left.38^{\circ} 53^{\prime} \mathrm{N} 35^{\circ} 44^{\prime} \mathrm{E}\right)$, Lake Yenikarpuzlu Dam, Edirne $\left(40^{\circ} 49^{\prime}\right.$ N $\left.26^{\circ} 19^{\prime} \mathrm{E}\right)$ and Lake Keban Dam, Elazig ( $38^{\circ} 38^{\prime}$ N $39^{\circ} 28^{\prime}$ E) (Fig. 1). The $A$. astaci prevalence in the first two populations was studied earlier (Kokko et al., 2012; Svoboda et al., 2012), while the last six populations' infection status has not been reported earlier.
Samples for the qPCR analyses of $A$. astaci were taken by cutting a piece of melanised cuticle or, in case of no melanised spots, a uropod from each crayfish. The samples were stored in absolute ethanol (Merck) by the Firat University staff in Turkey. The dissection tools were disinfected after every sampled crayfish tissue. The preserved samples were stored at $-21^{\circ} \mathrm{C}$ and then shipped by airmail to the University of Eastern Finland, Kuopio campus, for further analyses. In addition, a previous sample set from year 2011 (Kokko et al., 2012) with two locations (Tab. 1) were included into further analyses.

Before the DNA extractions, the tissue samples were rinsed in sterile water to remove the ethanol. DNA extractions were conducted with E.Z.N.A Insect DNA isolation kit (Omega BioTek) following manufacturer's instructions. The quantity and quality of the extracted DNA was measured with a NanoDropspectrophotometer (Thermo Fisher Scientific). For A. astaci prevalence screening, a quantitative TaqMan ${ }^{\circledR}$ minor groove binder (MGB; Applied Biosystems) real-time PCR assay (qPCR) developed by Vrålstad et al. (2009) was adjusted to LightCycler 480 II qPCR machine (Roche) and the sample volume was adjusted to $10 \mu \mathrm{L}$ similarly as in Kokko et al. (2012). TaqMan ${ }^{\circledR}$ Environmental Master Mix (Applied Biosystems) was used for the qPCR reactions (Strand et al., $2011)$ with $2 \mu \mathrm{L}$ of $1 \times$ and $10 \times$ diluted DNA. A calibrated standard curve (Vrålstad et al., 2009) was applied to determine the PFU values and agent levels for sampled crayfish tissues. Agent level A0 and A1 ( $<5$ PFU's) indicated negative samples, A2 (5-50 PFU's) very low level infection, A3 (50-1000 PFU's) low level infection, A4 $\left(10^{3}-10^{4} \mathrm{PFU}\right.$ 's $)$ moderate infection and agent level A5 ( $10^{5}-10^{6}$ PFU's) a high level infection.

Three different PCR amplicons of each sample showing agent level A3 or higher in qPCR were sequenced to further characterize the infections. The chitinase gene was amplified and sequenced for selected samples according to Makkonen et al. (2012b) and mitochondrial ribosomal small and large subunits, rnnS and rnnL, according to Makkonen et al. (2018). The obtained PCR amplicons were purified with QiaQuick 


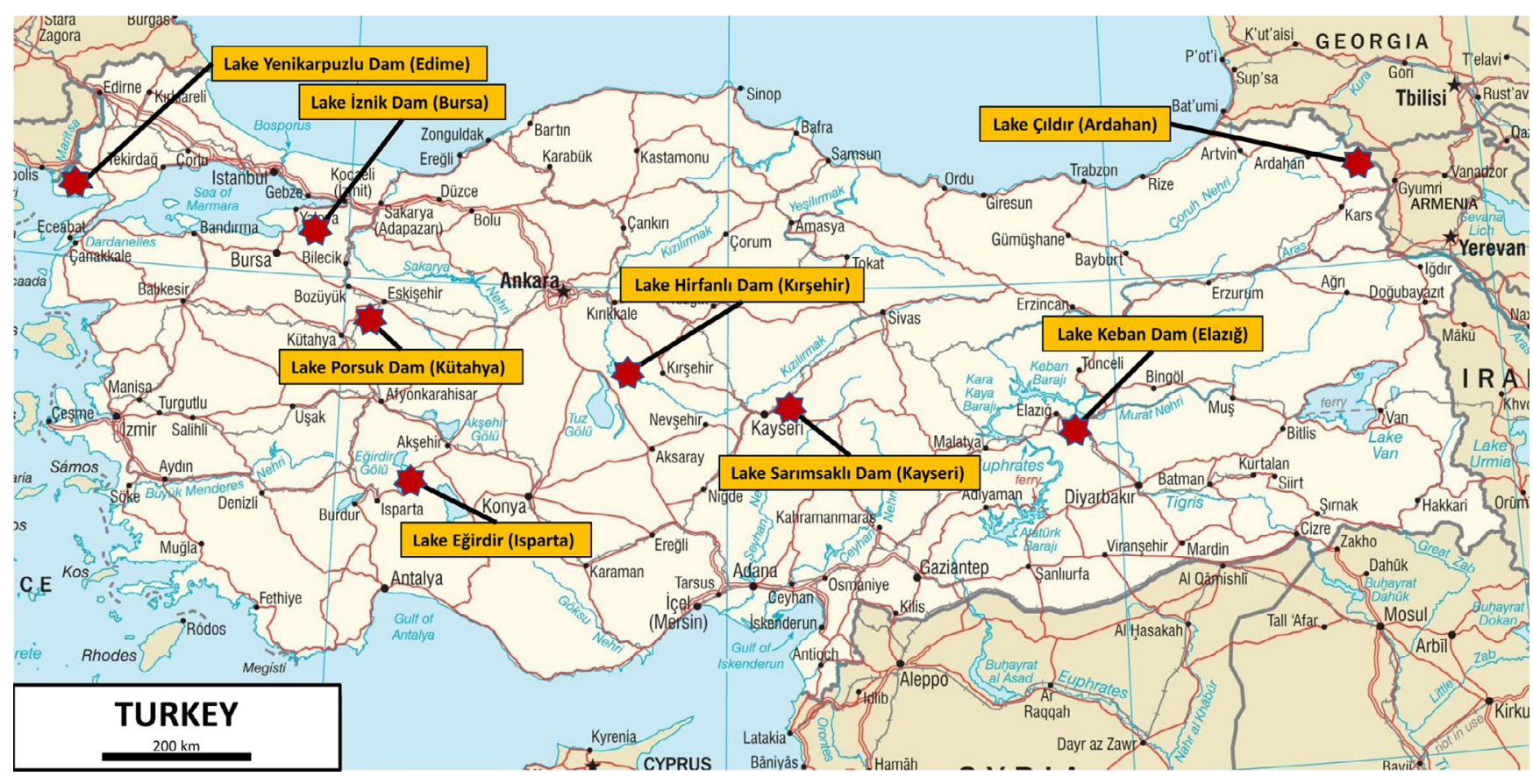

Fig. 1. Locations of the sampled Turkish narrow-clawed crayfish (Astacus leptodactylus) populations: Lake Çıldır, Lake Egirdir, Lake Hirfanlı Dam, Lake İznik Dam, Lake Keban Dam, Lake Porsuk Dam, Lake Sarımsaklı Dam and Lake Yenikarpuzlu Dam. Lake Hirfanlı Dam and Lake İznik Dam were analyzed earlier with qPCR by Kokko et al. (2012). Red stars indicate the proximate locations of the sampled water bodies.

PCR purification kit (Qiagen) following manufacturer's instructions and sequenced in GATC Biotech (Cologne, Germany). Sequences were submitted to GenBank with access numbers MG596357-MG596378.

Aphanomyces astaci infection was detected in seven of the eight narrow-clawed crayfish populations (Tab. 1), and, in six of those cases, also the haplotype of the disease agent was characterized with at least one sequence. In four cases, i.e., Lake Iznik, Lake Porsuk Dam, Lake Çıldır and Lake Sarımsaklı Dam, haplogroup A (As-genotype) was causing the latent infection. In two cases, i.e., Lake Yenikarpuzlu Dam and Lake Hirfanl 1 Dam, the infection was caused by the haplogroup B (PsI-genotype) of A. astaci. In Lake Hirfanlı Dam case, the haplogroup B infection was detected from both years' 2011 and 2012 samplings, indicating a latent infection caused by the haplogroup B in this site. In addition to $A$. astaci, single rnnS sequence similar to Saprolegnia ferax (99.1\%) was detected from Lake Porsuk Dam and a sequence similar to Pythium insidiosum (96.5\%) from Lake Yenikarpuzlu Dam. Furthermore, rnnS amplicon showing $97.4 \%$ similarity to $A$. astaci was detected from Lake Egirdir sample that was showing very low agent level (A2) in qPCR. Lake Keban Dam narrow-clawed crayfish population did not show infection gross symptoms, and also the qPCR detected only trace levels of $A$. astaci DNA, i.e., agent level A1 considered as negative (Tab. 1).

The detected infections can mainly be defined as latent $A$. astaci infections (Jussila et al., 2014), as the studied populations have been reported to be productive (Kokko et al., 2012; Svoboda et al., 2012) and show low level of infection gross symptoms (Tab. 1), even though they have variably collapsed since $A$. astaci spread into Anatolian peninsula (Köksal, 1988; Rahe and Soylu, 1989; Timur, 1990). The latent $A$. astaci infections might be caused by $A$. astaci strains of low virulence, while one of the $A$. astaci strains causing latent infection in Slovenian stone crayfish (Austropotamobius torrentium) has been shown to be virulent against noble crayfish (Jussila et al., 2017). The haplogroups of the observed $A$. astaci infections were determined according to Makkonen et al. (2018) using mitochondrial rnnS ad rnnL sequences. The grouping of $A$. astaci haplogroups is similar to the genotypes (Makkonen et al., 2018), and the detected haplogroup B (genotype B/PsI) strains carried by the signal crayfish (Pacifastacus leniusculus) are in most cases considered highly virulent (Aydın et al., 2012, 2014; Makkonen et al., 2012a, 2014) and no latent infections in European crayfish species caused by this haplogroup have been previously observed.

Our study shows a geographically widespread distribution of $A$. astaci among Turkish narrow-clawed crayfish populations. As those populations are still productive and have thus been commercially exploited, it seems that the Turkish narrowclawed crayfish could have considerably high resistance against both haplogroup A and B A. astaci infections, as has already been indicated (Unestam, 1969; Kokko et al., 2012; Svoboda et al., 2012, 2014, 2017), whilst there are also studies reporting significant susceptibility (Schikora, 1906; Alderman et al., 1987). This host-parasite co-evolution and adaptation possibility opens avenues for further studies on the relationship between $A$. astaci, other co-infecting pathogens and its native European crayfish hosts (e.g., Edgerton et al., 2004).

Regardless of the implications of a possibly elevated resistance of the Turkish narrow-clawed crayfish, the conserva- 
tion of the native European crayfish requires swift actions against the spreading of different strains of $A$. astaci among native European crayfish populations. On the other hand, our finding together with the recent latent crayfish plague observations from native European crayfish populations (Jussila et al., 2011; Viljamaa-Dirks et al., 2011; Kokko et al., 2012; Svoboda et al., 2012; Kušar et al., 2013; Jussila et al., 2017) might be indicating a brighter future for the European crayfish under the pressures from the crayfish plague disease.

Acknowledgements. The manuscript preparations were supported by LIFE + CrayMate project (LIFE12 INF/FI/233).

\section{References}

Alderman DJ. 1996. Geographical spread of bacterial and fungal diseases of crustaceans. Revue Sci Tech OIE 15: 603-632.

Alderman DJ, Polglase JL, Frayling M. 1987. Aphanomyces astaci pathogenicity under laboratory and field conditions. J Fish Dis 10: 385-393.

Aydın H, Harloglu MM, Deniz T. 2012. Harvest, export and economic status of freshwater crayfish (Astacus leptodactylus Esch. 1823) in Turkey. Afr J Agricult Res 7: 2463-2468.

Aydın H, Kokko H, Makkonen J, Kortet R, Kukkonen H, Jussila J. 2014. The signal crayfish is vulnerable to both the As and the PsI-isolates of the crayfish plague. Knowl Manag Aquatic Ecosyst 413: 10.

Edgerton BF, Henttonen P, Jussila J, Mannonen A, Paasonen P, Taugbøl T, Edsman L, Souty-Grosset C. 2004. Understanding the causes of disease in European freshwater crayfish. Conserv Biol 18: $1466-1474$

Güner U, Harlioglu MM. 2010. Status of freshwater crayfish distribution in Thrace region of Turkey. Rev Fish Sci 18: 1-6.

Harloglu MM. 2004. The present situation of freshwater crayfish, Astacus leptodactylus (Eschscholtz, 1823) in Turkey. Aquaculture 230: 181-187.

Harlioglu MM. 2008. The harvest of the freshwater crayfish Astacus leptodactylus Eschscholtz in Turkey: harvest history, impact of crayfish plague, and present distribution of harvested populations. Aquacult Int 16: 351-360.

Harloglu MM, Harlıglu AG. 2006. Threat of non-native crayfish species introductions into Turkey: global lessons. Rev Fish Biol Fisher 16: 171-181.

Jussila J, Makkonen J, Vainikka A, Kortet R, Kokko H. 2011. Latent crayfish plague (Aphanomyces astaci) infection in a robust wild noble crayfi sh (Astacus astacus) population. Aquaculture 321: 17-20.

Jussila J, Makkonen J, Vainikka A, Kortet R, Kokko H. 2014. Crayfish plague dilemma: how to be a courteous killer? Boreal Environ Res 19: $235-244$

Jussila J, Vrezec A, Makkonen J, Kortet R, Kokko H. 2015. Invasive crayfish and their invasive diseases in Europe with the focus on the virulence evolution of the crayfish plague. Chapter 8. In: CanningClode J, ed. Biological invasions in changing ecosystems. Vectors, ecological impacts, management and predictions. Warsaw/Berlin: De Gruyter Ltd, pp. 183-211.

Jussila J, Vrezec A, Jaklič T, Kukkonen H, Makkonen J, Kokko H. 2017. Aphanomyces astaci isolate from latently infected stone crayfish (Austropotamobius torrentium) population is virulent. $J$ Invertebr Pathol 149: 15-20.

Kokko H, Koistinen L, Harloglu MM, Makkonen J, Aydin H, Jussila J. 2012. Recovering Turkish narrow-clawed crayfish (Astacus leptodactylus) populations carry Aphanomyces astaci. Knowl Manag Aquat Ecosyst 404: 12.

Köksal G. 1988. Astacus leptodactylus in Europe. In Holdich DM, Lowery RS, eds. Freshwater Crayfish: biology, management and exploitation. London: Croom Helm Ltd, pp. 365-400.

Kušar D, Vrezec A, Ocepek M, Jenčič V. 2013. Aphanomyces astaci in wild crayfish populations in Slovenia: first report of persistent infection in a stone crayfish Austropotamobius torrentium population. Dis Aquat Organ 103: 157-169.

Makkonen J, Jussila J, Kortet R, Vainikka A, Kokko H. 2012a. Differing virulence of Aphanomyces astaci isolates and elevated resistance of noble crayfish Astacus astacus against crayfish plague. Dis Aquatic Organ 102: 129-136.

Makkonen J, Jussila J, Kokko H. 2012b. The diversity of the pathogenic oomycete (Aphanomyces astaci) chitinase genes within the genotypes indicate adaptation to its hosts. Fungal Genet Biol 49: 635-642.

Makkonen J, Kokko H, Vainikka A, Kortet R, Jussila J. 2014. Dosedependent mortality of the noble crayfish (Astacus astacus) to different strains of the crayfish plague (Aphanomyces astaci). $J$ Invertebr Pathol 115: 86-91.

Makkonen J, Jussila J, Panteleit J, Keller NS, Schrimpf A, Theissinger K, Kortet R, Martín-Torrijos L, Sandoval-Sierra JV, DiéguezUribeondo J, Kokko H. 2018. MtDNA allows the sensitive detection and haplotyping of the crayfish plague disease agent Aphanomyces astaci showing clues about its origin and migration. Parasitology, In Press.

Rahe R, Soylu E. 1989. Identification of the pathogenic fungus causing destruction to Turkish crayfish stocks (Astacus leptodactylus). J Invertebr Pathol 54: 10-15.

Schikora F. 1906 Die Krebspest. Fisch Ztg 9: 529-583.

Strand DA, Holst-Jensen A, Viljugrein H, Edvardsen B, Klaveness D, Jussila J, Vrålstad T. 2011. Detection and quantification of the crayfish plague agent in natural waters: direct monitoring approach for aquatic environments. Dis Aquat Organ 95: 9-17.

Svoboda J, Kozubíková E, Kozák P, Kouba A, Bahadir KS, Diler Ö, Diler I, Policar T, Petrusek A. 2012. PCR detection of the crayfish plague pathogen in narrow-clawed crayfish inhabiting Lake Egirdir in Turkey. Dis Aquat Organ 98: 255-259.

Svoboda J, Strand DA, Vrålstad T, Grandjean F, Edsman E, Kozák P, Kouba A, Fristad RF, Koca SB, Petrusek A. 2014. The crayfish plague pathogen can infect freshwater-inhabiting crabs. Freshw Biol 59: 918-929.

Svoboda J, Mrugała A, Kozubíková-Balcarová E, Petrusek A. 2017. Hosts and transmission of the crayfish plague pathogen Aphanomyces astaci: a review. J Fish Dis 40: 127-140.

Timur G. 1990. Crayfish plague in some lakes of Turkey. Bull Eur Ass Fish Pathol 10: 100-103.

Unestam T. 1969. Resistance to the crayfish plague in some American, Japanese and European crayfishes. Rep Inst Freshw Res Drottningholm 49: 202-209.

Viljamaa-Dirks S, Heinikainen S, Nieminen M, Vennerström P, Pelkonen S. 2011. Persistent infection by crayfish plague Aphanomyces astaci in a noble crayfish population - a case report. Bull Eur Ass Fish Pathol 31: 182-188.

Vrålstad T, Knutsen AK, Tengs T, Holst-Jensen A. 2009. A quantitative TaqMan MGB real-time polymerase chain reaction based assay for detection of the causative agent of crayfish plague Aphanomyces astaci. Vet Mic 137: 146-155.

Cite this article as: Kokko H, Harlioglu MM, Aydin H, Makkonen J, Gökmen G, Aksu Ö, Jussila J. 2018. Observations of crayfish plague infections in commercially important narrow-clawed crayfish populations in Turkey. Knowl. Manag. Aquat. Ecosyst., $419,10$. 